\title{
Climate change accounting: The challenge of uncertainty in Pacific Islands
}

\begin{abstract}
:
The paper aims to set out several key issues in relation to climate change research based on accounting and accountability. It also outlines using a case study of the Pacific Islands about the problem of uncertainty in relation to climate change, particularly in regards to the rising water levels and potential relocation of peasants from the atoll islands of Kiribati, Tuvalu and Marshall Islands. The literature on climate change accounting and the archival data on climate change from the Pacific Islands are reviewed. Some interviews with people located on the coastal areas of the Pacific Islands known to one of the researchers are conducted. The interviewees are from Kiribati and Fiji. Despite growing corporate activity on climate change, no meaningful progress is being made on GHG emissions reduction, and in some cases no meaningful progress is being made on natural Kyoto emission reduction targets, suggesting the continuation of a relatively weak policy regimes and 'business-as-usual'. However, the Paris agreement recognized the specific needs and special circumstances of developing countries and acknowledged that climate change is a common concern of human kind. The agreement resolved to hold the increase in global average temperature to well below $2^{\circ}$ above preindustrial levels and to pursue efforts to limit the temperature increase to $1.5^{\circ}$ above preindustrial level. Such modest increase would significantly reduce the risks and impacts of climate change. The research is limited to Pacific Islands only but provides avenue for such work to be extended to other research settings as well. The call for more research on climate change is arguably more relevant today given misgivings on market-based solutions and the consensus reached from the Paris agreement recently. There has been relatively little work done in climate change accounting in the Pacific Islands where an immense impact has been felt on people's lives and livelihoods as well as on important industries such as agriculture and tourism as a consequence of climate change such as rising water levels.
\end{abstract}

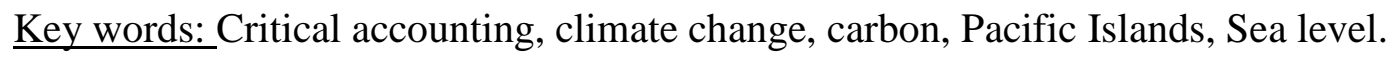




\section{Climate change accounting: The challenge of uncertainty in Pacific Islands}

\section{$\underline{1.0 \text { Introduction }}$}

Today's global economy is dominated by activities of large corporations that operate in many different economies of the world. We argue that their activities and their accounting practices recognize and promote sectional interests such as those of the providers of the capital (Cooper and Sherer, 1984). In these circumstances it is highly unlikely that social welfare for global citizens will be enhanced. These relations are filled with contradictions, conflicts, tensions and antagonisms (Tinker, 1985, 2014; Sy and Tinker, 2014a). For example, there is hardly any industrialisation in the South Pacific region, yet the nations forming part of the Region are the earliest ones to feel and experience the rising sea levels arising from global warming.

The desire to meet human needs particularly in terms of quality, safety and sustainability among others, still occupy a back stage in many economies of the world. Sustainability in general and climate change in particular are important social welfare issues and their current state of affairs remains a critical concern for the global world. We argue that social welfare is likely to be enhanced if corporations pro-actively tackle the environmental issues and problems and disclose them in their corporate annual reports and other publications in an unbiased manner. These measures are likely to have positive implications in enhancing the social welfare values. Accountants and the accounting profession have knowledge and skills to contribute to the global climate change agenda (Chartered Institute of Management Accountants, 2010). These issues are discussed elsewhere in the paper.

The paper aims to set out several key issues in relation to climate change research based on accounting and accountability. The scientific evidence continues to be predominant. According to Anderegg et al., (2010) 97 to 98 percent of the scientific community appears to accept the primary conclusions of the IPCC that it is 'very likely' that 'most' of the warming of the Earths average temperature over the second half of the twentieth century is owing to anthropogenic gas (GHG) emissions. International proposals to avert 'dangerous' climate change include targets for stabilising atmospheric GHG concentration (Milne \& Grubnic, 2011). These include possible 
emission cuts of 80-90 percent by 2050 with significant cuts required immediately or very soon (e.g. Meyer, 2000). Most countries are currently committed to a modest reduction in GHG emission under the Paris Agreement.

An increased interest has been shown in carbon accounting, GHG inventories (carbon foot printing) with a number of organisations in recent years proclaiming gained efficiencies in their carbon management strategies and/or their ‘carbon neutrality’ (Hoffman, 2007). However, much more work needs to be done to tackle the actual dynamics of organizational emissions reductions programmes (Ball et al., 2009). Despite growing corporate activity on climate change, no meaningful progress is being made on global GHG emission reduction, and in some cases, no meaningful progress is being made on natural Kyoto emission reduction targets, suggesting the continuation of relatively weak policy regimes and 'business-as-usual' (Jones \& Levy, 2007). It is argued that climate change is the greatest challenge of the $21^{\text {st }}$ Century. Many scientists believe that the planet has reached a crucial tipping point in relation to climate change and that immediate action is essential (IPCC, 2007). Accordingly, given the challenge of climate change, a reduction in carbon emissions is becoming an important aspect of an organisation's environmental performance (Pellegrino \& Lodhia, 2012).

The paper outlines using a case study of the Pacific Islands the problem of uncertainty in relation to climate change, particularly in relation to the rising water levels and potential relocation of peasants from the atoll islands of Kiribati, Tuvalu and Marshall Islands. The paper is organized as follows: Section 2 outlines the literature on climate change accounting. Section 3 delineates the research method. The case study results are presented in Section 4. Section 5 finally discusses the narrative and concludes the paper.

\subsection{Climate Change accounting}

The volume of cars and air transport has increased over the years, subsequently increasing the carbon emission as well. While fuel burn efficiency improvements will continue, they will not keep pace with the increase in capacity (Milne \& Grubnic, 2011). The aviation industry is under some pressure to establish its environmental credentials. A review of Air New Zealand's website and annual reports reveal references to increased efficiency through fleet upgrades, 
savings of carbon emissions through plane modifications, reduction in $\mathrm{CO} 2$ emission per million available seat kilometres. Air New Zealand (2007, p.2) points out:

Carbon emissions are an inevitable consequence of air transportation and will continue to remain so, despite technological advancements, for the foreseeable future. However, as a small, geographically isolated country, air transport is vital in providing economic links to international markets....As New Zealand's national carrier, we are absolutely committed to playing our part in ensuring that our environmental impact is minimized. We must continue to bring tourists to New Zealand, and remain committed to managing the environmental impact we have in the process.

According to BHP Billiton (2009, p.13) "we believe that the risk of climate change associated with increasing greenhouse gas concentration in the atmosphere need to be addressed through accelerated action.” BHP Billiton (2009) discloses that it has created the world's first power plant fueled by coal mine ventilation air, which will reduce the company's greenhouse gas emissions by 2,500t of carbon dioxide equivalent per year. The company's amplifies its commitment to making real changes by pursuing emissions abatement, such as its US \$300 million investment over 5 years from June 2007 to "support the research, development and demonstration of low-emissions technologies, including clear coal and carbon sequestration technologies” (BHP Billiton, 2009, p.44).

Nearly half of New Zealand's GHG emissions come from agriculture, and substantial forests are considered available to offset emissions. According to Bui (2009) firms with higher emission levels are more interested in the government's recognition of emission removal activities. New Zealand had introduced Emission Trading Scheme, as other countries are doing. At best, one might argue such a scheme has prevented what might otherwise have been further increases in gross emissions of carbon dioxide- agriculture and methane are yet to enter the scheme.

According to Stechemesser and Guenther (2012) in order to reduce the global climate change triggered by anthropogenic greenhouse gases, every nation must reduce its individual greenhouse gas emission or increase the possible carbon sinks. Some countries have partly transferred this responsibility to organisations. The call for more research on sustainability (including climate 
change) accounting and accountability in the public sector, as put forward by Ball and Grubnic (2007), is arguably more relevant today given misgivings on market-based solutions. The predominant agenda to date on climate accounting has focused on the political and policy response involved in accounting for carbon emissions through the use of carbon markets. To commoditise carbon and make carbon markets work, accounting is of particular importance (Lovell \& Mackenzie, 2011). According to Pelligrino and Lodhia (2012), climate change accounting or carbon accounting is a subset of sustainability accounting and focuses extensively on carbon emissions. Authors such as Bebbington and Larrinnaga-Gonzalez (2008) contend that carbon accounting practices have increasing significance due to the global problem of climate change. It is generally believed that controlling carbon emissions is critical and that management and reporting practices can be applied to carbon issues (Burritt et al., 2011).

We seek to answer key empirical questions about the governance of climate change by accountants: how have the accountants been involved in the day-to-day governance of climate change to date? Miller \& Hopwood (1994, p.9) suggest, "Accounting could not and should not be studied as an organizational practice in isolation from the wider social and institutional contexts in which it operates." In other words, social processes shape and are shaped by accountancy (p.9). From a governmentality perspective, calculation and measurement are critical to governance process (Miller, 1991), as Dean (1999) explains: "An analysis of government, then, is concerned with the means of calculation, both qualitative and quantitative” (1999, p.11 emphasis added).

Accountants have to date not been at the forefront of climate change action, but have nevertheless significantly increased their activities and interests in the problem in recent years and a number of international networks have emerged (e.g. the Climate Disclosure Standards Board, Accounting for Sustainability, Global Reporting Initiative, International Integrated Reporting Council). More broadly the response of accountants to the issue of climate change during the late 1990s and early twenty-first century fits with ideas from accountancy and society literature about the close links between accountancy and wider society. 
It was in 2008 that the main global accountancy standard setter-the International Accounting Standards Board (IASB) relaunched its Emission Trading Scheme Project, this time in conjunction with the US Financial Accounting Standards Board (FASB) (IASB 2008) in an attempt to resolve the longstanding ambiguity- since the withdrawal of IFRIC-3- about how to account for carbon credits. This new joint IASB-FASB project has a somewhat broader remit too: it is not just about the EU ETS but aims to address the accounting of all tradable emissions rights and obligations arising under any emission trading schemes, including New Zealand, Australia, and existing and proposed schemes in the United States- thus reflecting the international growth of emissions trading since the turn of the century.

Much of the criticism of carbon markets is not about the idea of putting a monetary value on carbon per se, but about whether it is better to control greenhouse gas emissions through setting emission standards (and then allowing trading, so-called “cap and trade”) or by charging the appropriate pollution taxes (Hepburn, 2006). In accountancy companies, the discussion on the integration of aspects of climate change mitigation into accounting is often called carbon accounting (KPMG, 2008; Stechemesser \& Guenther, 2012). A broad definition of 'carbon accounting' is given by Hespenheide et al., (2010), who indicate the measuring of emissions and removals on the one hand and the implications for finances on the other hand. This definition entails inclusion of non-monetary as well as monetary aspects from an organizational perspective, and they also describe the internal and external application of carbon accounting. Ratnatunga (2007) specifies the measurement for the calculation of carbon emissions as follows: "the mechanism for calculating the quantum of CO2 either emitted by a source or sequested in a biomass sink is referred to as 'carbon accounting' (p.8), but he notes that because they omit monetary value, they refer instead to "carbon emission and sequestration accounting." The reduction of carbon emission has been on the agenda of World leaders. The 2015 Paris agreement is a step forward in accomplishing carbon reductions. The ensuing section discusses this. 


\subsection{The Paris Agreement for Global Climate Action}

With China and the USA, the world's largest industrialised nations recently announcing their intentions to address climate change, a global initiative to address this was imminent. This resulted in parties to the UN Framework Convention on Climate Change to adopt the Paris Agreement on 12 December 2015. This agreement is a new legally binding framework that is internationally coordinated to tackle global climate change in the period after 2020 and will replace the Kyoto Protocol (The Paris Agreement, Article 2; Erbach, 2016). The main objective of the agreement is to maintain the increase in global temperatures well below 2 degrees Celsius on pre-industrial averages with a more ambitious target of limiting the increase to 1.5 degrees Celsius. In order to achieve this goal, the parties to the Paris agreement will require profound changes to their economies (The Paris Agreement Article 2.1; Climate Focus, 2015). The Paris Agreement establishes obligations of all parties to contribute to climate change mitigation and adaptation. This requires all countries to develop plans to contribute towards mitigation and adaptation and communicate them to the Secretariat of the Convention expressed in nationally determined contributions (The Paris Agreement, Article 2). To attain the emission targets as per the Agreement, enormous emission reductions are required and may even require the use of even negative emissions technologies such as large scale energy storage, advanced nuclear power, carbon capture and substantial afforestation (Erbach, 2016).

Unlike the Kyoto Protocol, the Paris Agreement does not formulate specific emissions targets, instead, it depends on voluntary mitigation contributions and a series of processes that seek to ensure collective and individual progress in meeting the initial and progressively more ambitious mitigation contributions (Erbach, 2016). Each Party to the contract shall prepare, maintain and communicate their national determined contributions (NDCs) every five years with progression beyond their last NDC. Developed countries are expected to adopt economy wide absolute emission reduction targets immediately while developing countries will aim for this overtime in view of different national circumstances (Climate Focus, 2015). However, developing countries 
will be provided support in terms of finance and technology in order to allow them to raise their ambitions on emissions reduction.

With regard to transparency and accountability, parties shall be held accountable for their NDCs through an enhanced transparency framework for action and support with flexibility provisions for developing countries (The Paris Agreement, Article 4 and 13). To enhance accountability, parties to the agreement are expected to provide a report on a regular basis on emissions and removals together with information on progress made in implementing and achieving their NDCs.

The Paris Agreement is not without limitations. There is no stipulation of an emission budget or quantified reductions in emissions that would be necessary to achieve the overall goal of holding the global temperatures well below 2 degrees Celsius and efforts to limit the increase to 1.5 degrees. There is no formal mitigation commitment that is enforceable and there is no provision for carbon pricing. Although the agreement addresses losses and damages, there is no provision in the agreement on liabilities and compensations. Finally, there is no mention in the agreement about the major sectors of the global economy with large and growing greenhouse gas emissions. Among these are aviation and shipping. We now examine the issue of accounting on climate change.

\subsection{Accounting and Accountants on Climate Change}

Climate change is a global issue and therefore global attention and solutions are needed to tackle the unintended consequences of climate change. The Kyoto Protocol and the Paris Agreement are global initiatives on climate change. If global calls for climate change are to have any effect on global organisations, then climate change needs to be engrained or integrated within their strategies and climate change as a strategic goal.

The extended value chain of an organisation that includes suppliers, their suppliers, customers and their customers are also keen to know climate change commitments of parties within the extended value chain. Employees are no exceptions. To implement strategies people down the 
line must be knowledgeable about them, including goals, mission and vision. Research findings in this regard are mixed and investment in training is a value added activity.

Accountants are part of the senior management group or the strategic apex and this demonstrates that they can have a proactive role in sustainability management, in particular, their contributions with regard to strategy formulation, implementation and monitoring on climate change (Riva, 2015; Quayle, 2014; Mistry, Sharma \& Low, 2014; Sharma \& Kelly, 2014, 2015). In this way achieving sustainability becomes a fundamental strategic goal for businesses. With regard to specific accounting tools and techniques, the following could be adapted to help organisations manage their environmental impacts: cost benefit and profit analysis, environmental investment appraisal, environmental cost report, environmental balanced scorecard, life cycle cost assessment, among others (CIMA, 2010). While financial accountants' roles are more reflected in climate change reporting issues, it is the management accountants who are better equipped with skills and training, enabling organisations to adapt and mitigate to climate changes. We argue that it is actually tackling the climate change problems and the performance of companies on climate change that is more important. In this regard fundamental changes are essential in the operations of organisations in order to deliver results on climate change. Reporting issues then should incorporate the above, rather than just focusing on compliance issues. Many firms are in a habit of making only general disclosures with emphasis on good news disclosures only.

It is argued that organisations that have integrated climate change into their strategies are likely to be well positioned and have greater shareholder and stakeholder value compared to those organisations that are poorly positioned (Sharma \& Davey, 2013; Sharma, Low \& Davey, 2013).. While to date climate change is not very high on the agenda of many organisations, yet there is a feeling among many that it is important and is here upon us to stay indefinitely and companies worldwide need to do a lot more.

If the senior management has positive commitments on climate change and have integrated sustainability issues into their strategies, then this should result in identification of key climate change performance indicators against which an organisation's actual performance on climate change could be gauged. Many firms these days use a strategic performance measurement tool 
known as the balanced scorecard (Kaplan and Norton, 1996). A balanced scorecard translates strategies into a set of key performance indicators and firms could incorporate climate change key performance indicators on either their existing balanced scorecards or redesign it to incorporate KPIs on climate change separately. A proactive initiative such as the above has potential to create a long term sustainable value for shareholders and other wider stakeholders. If long term value is compared with short term costs, then the former is likely to exceed the latter.

We further argue that investor expectations are changing and they expect more reliable reporting on benefits, risks and costs associated with climate change initiatives. Management accountants, given their educational background, experience and skills are uniquely placed to provide quantitative as well as qualitative information on costs/benefits associated with climate change (Mistry et al., 2014). Analytical and risk management skills of accountants can assist organisations to understand better the strategic and practical effects of sustainable business practices and influence senior management attitude and involvement in this crucial area. Accountants can make information available that captures return on climate change investment initiatives thereby helping the stakeholders to capitalise on climate related financial gains. Accountants could also provide valuable advice on tax implications for green projects, government incentives schemes and measurement and reporting of emissions. To conclude this section, accountants and the accounting profession have the skills to influence sustainable strategic and operational decisions in organisations thus making a vital contribution to the global climate change agenda. The next section outlines the research method for the study.

\subsection{Research Method}

The literature on climate change accounting and the archival data on climate change from the Pacific Islands are reviewed. Five interviews with people located on the coastal areas of the Pacific Islands known to one of the researchers are conducted. The five interviewees are from Kiribati and Fiji.

Interviews lasted between an hour to an hour and half and took place at respondents' premises which were located close to the beaches. Semi-structured interviews were conducted. The interviewees were free to answer questions outside the interview schedule and sometimes their 
responses were probed further. At least three interviews were taped and the other two respondents opted not to be taped and so handwritten notes were made by one of the researchers. Interview transcripts were given back to the respondents for verification purposes.

The interview data was analyzed for patterns and themes. Themes such as climate change, rising sea levels, people's livelihoods, The 2015 Paris Agreement were drawn from the interview responses.

\subsection{Case Findings of the Pacific Case Study}

People living in small tropical islands are experiencing changes and variability in their climate change such as shifts in rainfall patterns, increasing frequency of some extreme weather events and rising sea levels (Climate Change in the Pacific, 2011). These changes are affecting peoples’ lives and livelihoods as well as important industries such as agriculture and tourism.

Sea level has been rising globally including the Pacific region over the recent decades. Extreme high sea levels are also increasing primarily as a result of increases in mean sea level. As a consequence of higher carbon dioxide (CO2) concentrations in the atmosphere, the oceans are absorbing more $\mathrm{CO} 2$. The $\mathrm{CO} 2$ taken up by the ocean reacts in water and causes a decrease in the $\mathrm{pH}$ of the sea water that is referred to as ocean acidification (Climate change in the Pacific, 2011). Acidification is accompanied by a decrease in the sea water saturation state of carbonate minerals that are secreted as shells and skeletal material by many key species in reef ecosystem (ibid, 2011). Aragonite is the form of calcium carbonate precipitated by reef building corals and studies have shown that coral growth declines as the aragonite saturation state of sea water decreases (ibid, 2011).

Aragonite saturation states above a value of 4 are considered optimal for coral growth and for the development of healthy reef ecosystems. According to Climate Change in the Pacific (2011), throughout most of the sub-tropical and tropical Pacific Island region, the saturation state in preindustrial times exceeded 4. By the mid-1990s, the uptake of anthropogenic CO2 had resulted in a widespread decline in the aragonite saturation state. 
The projected growth in atmospheric $\mathrm{CO} 2$ concentration is expected to cause further ocean acidification. Aragonite saturation values below 3.5 are projected to become more widespread and have the potential to disrupt the health and sustainability of reef ecosystems. According to Climate Change in the Pacific (2011), the lowest values of aragonite saturation in the region of the Partner Countries are projected to occur in the eastern equatorial Pacific, to the east of longitude 160 degree west affecting the eastern most islands of Kiribati, with the highest values in the region of the South Equatorial current, affecting the islands of the Cook Islands, Samoa and Tuvalu.

\subsection{Impact of climate change on Pacific Island citizens}

This section examines the interview evidence from the interviewees on climate change. Extreme sea levels can cause significant coastal impacts, including inundation of low-lying coastal terrain, erosion of beaches, ecosystem loss, damage or destruction of coastal infrastructure, damage to crops and water supplies, and injury or loss of life. According to a Kiribati lady: "The changes happen so fast- high tides and storms are more frequent and more destructive than ever. One day the islands will be uninhabitable" (Oxfam, 2015). On the island of Abemama, they have seen several houses washed away by high tides, and trees that used to bear coconut and breadfruit now stand bear. "The sea walls seem to be the only way to protect my land, but we build them with stones that are not strong enough to withstand the tides. We need concrete, but we can't afford it.”

"Our foods are fish, breadfruit, coconuts and babai (taro). But not everyone can grow local foods now, so they now depend on imported items like rice. But we still need money to buy it. Our main source of income is coconut copra, but coconut trees are not so fruitful these days,” Keene, from Kiribati laments.

Rotitaake, another individual from Kiribati, says he heard about talks about leaving the islands, but believes many people would not like to abandon their country. "Kiribati is where I belong. I love my country. But if things are going worse, there is no choice. The developed countries are doing that- burning those fuels- but not the islands. We are facing the disaster.” 
Officials in Tuvalu (965km) north of Fiji have been some of the most vocal critics of the world's largest greenhouse emitters- industrialized nations such as the United States and China. They accuse these nations of not doing enough to curb carbon emissions, contributing to the melting of ice sheets and rising seas. According to Warne (2015), Tuvalu's Prime Minister spoke in the 2014 Climate Summit in Peru as:

"I carry a huge burden and responsibility. Climate change keeps me awake at night. Will we survive or will we disappear under the sea?"

These were the desperate questions being asked. Are island nations like Tuvalu, where most of the land is barely above sea level destined to sink beneath the waves, like modern-day Atlantises? Are questions that haunt the policy makers in Tuvalu.

Scientific and anecdotal evidence suggests recent changes in sea levels, weather patterns, fisheries and agricultural productivity in Pacific Island countries. Pacific Islands have a high ratio of shoreline to land area that they are susceptible to damage from rising sea levels (Climate Change in the Pacific, 2011). Of all the Pacific Island countries, the four atoll states of Kiribati, the Marshall Islands, Tokelau and Tuvalu are particularly vulnerable as their fresh water reserves are limited to a shallow subsurface lens which is susceptible to depletion in drought and susceptible to contamination from salt water. Further, the height of atolls above sea-level rarely exceeds 2 metres, which makes them highly susceptible to wave damage (Barnett, 2001). The particular vulnerability of these atoll states raises the possibility of the first extinction of a Sovereign State due to environmental change.

At Paris meeting of COP 21, the Prime Minister of Fiji Frank Bainimarama asked the global leaders to visit the Pacific to experience the reality of climate change. He remarked: "we gather together in Paris as members of the human family at a critical point in global history. The rising sea levels and extreme weather events caused by climate change are already beginning to destroy our islands and our way of life. And if the world doesn't act decisively now to reduce the carbon emissions of the industrialized nations, we are doomed." He went on to say that Paris was his last hope. He further remarked: 
"As well as creating a whole new category of dispossessed - climate refugees. The people of entire nations, in some cases, having to find new homes. The crisis includes the loss of three nations- Kiribati, Tuvalu and the Marshall Islands.”

Fiji had began the process of relocating 45 communities and had so far identified 830 that were at risk (Fiji Times, December 2, 2015). Fiji's carbon emissions are minute proportion of the global output- 0.04 per cent.

In a village of Navuniyevu, Bua, the impact of climate change can be felt. According to the Fiji Times (December 15, 2015), the villages have seen these changes happen over past 30 years. A village headman, Wale Rabanalagi claimed when he was in secondary school, houses were built 10 metres away from the village shore line. "When I was in school the waves used to be 10 metres out but now it has covered our old sea wall built by our fathers and grandfathers and has claimed the 10 metre area," he said. "Last month, during the moon tide, the waves came into the village compound and we are lucky that all houses by the shore are built on posts. Otherwise the houses would have been flooded but we are seeing the effects of climate change here in our village." Mr Rabanalagi said "posts of old houses remained in the area now under water." He went on to say:

"When organisations and the Government talk about climate change issues, we know exactly what they are saying because we face the impact. So our contribution has also been discussed and we have reminded our villagers to leave the mangroves alone and no littering by the seaside. There are some little things we can do to save our village and as much as we can we are not interfering with nature so we leave the trees alone too." The next section brings the narrative together and concludes the paper.

\subsection{Discussion/ Conclusion}

This paper examines several key issues in relation to climate change research based on accounting and accountability. It also outlines using a case study of the Pacific Islands about the problem of uncertainty in relation to climate change, particularly in relation to the rising water levels and potential relocation of peasants from the atoll islands of Kiribati, Tuvalu and Marshall Islands. 
The Pacific Islands case provides a useful context for this research as the impact of climate change is creating concern for the Pacific Islanders, suggesting the need to examine the environmental disclosure of not only individual companies but also those of industry bodies, both locally and in the global context. Voluntary environmental disclosure may be implemented strategically. Altering society's expectation (lobbying) against carbon emission may partly solve the problem of climate change. Therefore, disclosures of carbon emission information may not only contribute to maintaining organizational legitimacy, but also system-wide legitimacy for all industries (Pellegrino \& Lodhia, 2012).

Our work extends the carbon accounting literature discussed earlier in the paper. The findings do have international relevance. The industrialized nations need to reduce the carbon emissions as that will have a flow on effect on the Pacific Islands and may assist to curb rising water levels. For instance, Pallegrino and Lodhia (2012) note that Australia's mining boom has provided the foundation of its well-being but at the same time, contributed to extensive carbon emissions both locally and internationally through its adverse and highly visible environmental impacts along with its coal exports.

The risk and uncertainty (Bebbington and Larrinaga-Gonzalez, 2008) shaped by mining industries activities to global climate change needs to be reported. Carbon reporting is only an initial step towards managing climate change and has potential to incorporate externalities into mainstream business practices (Pollegrino and Lodhia, 2012). Carbon reporting should be related to efforts to reduce carbon emissions by industrialized nations; and a real performance improvement in carbon emission is desired. The industrial nations need to be part of the global solution to climate change. The Paris Agreement in 2015 was part of this deal. Industrialised nations need to realize that business as usual is unacceptable and radical changes to organizations activity is warranted to ensure the survival of all beings on the planet. Our society has undergone enormous transformation at the different phases of societal development and the response to the climate change should not be viewed as any different. 


\section{$\underline{\text { Glossary of Terms }}$}

$\begin{array}{ll}\begin{array}{l}\text { Glossary } \\ \text { COP21 }\end{array} & \begin{array}{l}\text { Definitions } \\ \text { ETS }\end{array} \\ \text { GHG } & \text { Greenhouse gas } \\ \text { IFRIC } & \text { International Financial Reporting Interpretations Committee } \\ \text { Kyoto Protocal } & \text { Convention on Climate Change (UNFCC) that commits state } \\ & \text { parties to reduce GHG } \\ \text { NDC } & \text { Nationally determined contribution } \\ \text { Paris Agreement } & \text { 2015 United Nations Climate Change Conference agree on } \\ & \text { Outcome. }\end{array}$

\section{References:}

Air New Zealand annual report (2007).

Anderegg, W.R.L; Prall, J.W; Harol, J. and Schneidra, S.H. (2010). Expert credibility in Climate change, Proceedings of the National Academy of Sciences of the United States of 
America, vol.107 (27), pp.12107-9.

Ball, A. and Grubnic, S. (2007). Sustainability accounting and accountability in the public sector, in Unnerman, J; Bebbington, J. and O’Dwyer, B. (Eds), Sustainability Accounting and Accountability, Routledge, Abingdon, pp.243-65

Ball, A; Mason, I; Grubnic, S. and Hughes, P. (2009). The carbon neutral public sector: Early developments and an urgent agenda for research, Public Management Review, vol.11 (5), pp.575-600.

Barnett, J. (2001). Adapting to climate change in Pacific Island countries: The problem of uncertainty. World Development, vol.29 (6), pp.977-993.

Bebbington, J. and Larrinaga-Gonzalez, C. (2008). Carbon trading: accounting and reporting issues. European Accounting Review, vol.17(4), pp.697-717.

BHP Billiton (2009). BHP Billiton Annual Report 2009. http://www.bhpbilliton.com.au/bbContentRepository/docs/annual report2009.pdf.

Bui, B. (2009) Political strategy for performance management in a carbon-constrained operating context: The role of industry and firm characteristics, SSRN Electronic Journal. http://ssrn.com/abstracts=1371407. Downloaded 12 March 2016.

Burritt, R.L., Schaltegger, S. \& Zvesdov, D. (2011). Carbon management accounting practice in leading German companies, Australian Accounting Review, vol.21(1), pp.80-98.

Chartered Institute of Management Accountants (2010) Accounting for climate change: how management accountants can help organisations mitigate and adapt to climate change, pp 1-18, London.

Climate Change in the Pacific: Scientific Assessment and New Research (2011) (Vol.1 Regional Overview), Australian Bureau of Meteorology and Commonwealth Scientific and Industrial Research Organisation. 
Climate Focus (2015) The Paris Agreement Summary, December, Amsterdam.

Cooper, D. J., Sherer, M. (1984) The value of corporate accounting reports: arguments for a political economy of accounting, Accounting, Organistions and Society, pp. 207 - 232.

Dean, M. (1999). Governmentality: Power and Rule in Modern Society. London: Sage.

Erbach, G. (2016) The Paris Agreement: a new framework for global climate action, European Parliamentary Research Service, European Parliament, European Union.

Herpburn, C. (2006) Regulation by prices, quantities or both. Oxford Review of Economic Policy, vol.22 (2), pp.226-247.

Hespenheida, E., Pavalovsky, K. and McElory, M. (2010). Accounting for sustainability performance, Financial Executive, 26(2), ppp.52-58.

Hoffman, A.J. (2007).Carbon Strategies: How Leading Companies are Reducing their Climate Change Footprint, The University of Michigan Press, Ann Arbor, M1.

IASB (2008).International Accounting Standards Board (IASB) - Information for Observers:

Emission Trading Schemes; Board Meeting 20 May 2008. http://www.iasb.org/NR/rdonlyres/92B01EDC-E519-431F-915F0F33505D7DFD/0/ET50805b03065.pdf (last accessed 13 January 2016).

IPCC, 10 February 2007. 2007 Intergovernmental panel on climate change. Accessed at http://www.ipcc.ch/

Jones, C.A. and Levy, D. (2007). North American business strategies towards climate change, European Management Journal, vol.25 (6), pp.428-440.

Kaplan, R. S., and Norton, D. P. (1996). The balanced scorecard, Harvard Business School Press, Boston.

KPMG (2008). Accounting for carbon. The impact of carbon trading on financial statements. http://www.kpmg.com/BE/en/IssuesAnd Insights/ArticlesPublications/Documents/Accounting-for-Carbon.pdf. 29 April 2016.

Lovell, H. and Mackenzie, D. (2011). Accounting for carbon: The role of accounting 
professional organisations in governing climate change, Antipode, vol.43, pp.704-730.

Meyer, A. (2000). Contradiction and Convergence: The Global Solution to Climate Change, Green Books, Totnes, for the Schumacher Society.

Miller, P. (1991). The Foucault Effect: Studies in Governmentality in G.Burchill, C.Gordon \& P.Miller (eds), University of Chicago Press.

Miller, P. \& Hopwood, A. (1994). Accounting as Social and Institutional Practice, Cambridge University Press.

Milne, M. \& Grubnic, S. (2011) Climate change accounting research: Keep it interesting and different, Accounting, Auditing and Accountability Journal, Vol.24 (8), pp.940-977.

Mistry, V., Sharma, U., \& Low, M. (2014). Management accountants' perceptions of their role in accounting for sustainable development: An exploratory study. Pacific Accounting Review, 26(1/2), 112-133.

Oxfam New Zealand (2015) High Trade Talks From Paris to the Pacific, http://www.oxfam.org.nz. Downloaded 14 January 2016.

Pellegrino, C. and Lodhia, S. (2012).Climate change accounting and the Australian mining industry: Exploring the links between corporate disclosure and the generation of legitimacy, Journal of Cleaner Production, vol.36, pp.68-82.

Quayle, A. (2014). Making climate change manageable: How accounting constructs new powerknowledge regimes, Critical Perspectives on Accounting Conference, 6-9 July 2014, York University, Canada.

Ratnatunga, J. (2007). An inconvenient truth about accounting, JAMAR, vol.5 (1), pp.1-20.

Riva, D. (2015) Accountants can help fight climate change, Economia, Institute of Chartered Accountants of England and Wales, London.

Sharma, U., \& Davey, H. (2013). Voluntary disclosure in the annual reports of Fijian companies. International Journal of Economics and Accounting, 4(2), 184-208. 
Sharma, U., \& Kelly, M. (2014). Students’ perceptions of education for sustainable development in the accounting and business curriculum at a Business School in New Zealand. Meditari Accountancy Research 22(2), 130-148.

Sharma, U., \& Kelly, M. (2015). The changing role of accounting education and management control systems in the age of sustainability. International Journal of Critical Accounting, 7(3), 289-303.

Sharma, U., Low, R., \& Davey, H. (2013). Developments in non-monetary disclosures in annual reports of companies: A case study. International Journal of Economics and Accounting, 4(4), 297-326.

Stechemesser, K. and Guenther, E. (2012). Carbon accounting: A systematic literature review, Journal of Cleaner Production, vol.36, pp.17-38.

Sy, A., \& Tinker, T. (2014a). The return of paper prophets a social critique of mainstream accounting: Up-to-dated by Professor Sy. African Journal of Accounting, Auditing and Finance, 3(3), 171-178.

The Fiji Times, December 2, 2015.

The Fiji Times, December 15 2015, Sea Level Rise Claims Dwelling over 30 years.

The Paris Agreement (2015) United Nations Framework Convention On Climate Change.

Tinker, A. M. (1985) Paper Prophets, Holt, Rinehart and Winston, London.

Tinker, T. (2014). Love Canal and the return of paper prophets: A social critique of mainstream accounting. African Journal of Accounting, Auditing and Finance, 3(2), 143-148.

Warne, K. (2015). Will Pacific Island nations disappear as sea rise? May be not. National Geographic, February 13, 2015. 